\title{
The Effect of Implementing Enterprise Resource Planning (ERP) System on Earnings Management
}

\author{
Beatrix P. Danduru1, Rifka A. Inayah ${ }^{2}$, Annisa Nurfaidah ${ }^{3}$, Grace T. Pontoh ${ }^{4}$ \\ \{putridanduru@gmail.com ${ }^{1}$, rifkaulinayah@gmail.com ${ }^{2}$, Annisa.nurfaidah@yahoo.com ${ }^{3}$, \\ gracetpontoh@fe.unhas.ac.id $\left.{ }^{4}\right\}$ \\ Master of accounting student, Universitas Hasanuddin, Makassar, Indonesia ${ }^{1-3}$ \\ Accounting Department of Universitas Hasanuddin, Makassar, Indonesia ${ }^{4}$
}

\begin{abstract}
This study examines the relationship between ERP system implementation and earnings management. The study population is basic and chemical industry companies listed on the Indonesia Stock Exchange (IDX). The sample in this study is in the form-annual financial statements of 11 companies that meet the criteria for purposive sampling. The financial statement period is set 3 years before the implementation of the ERP system, and the financial report is three years after the implementation of the ERP system. Research shows that financial statements produced with ERP systems are not able to reduce the existence of manipulation of financial data. The amount of investment and exceed expectations of the implementation of the ERP system is the reason for the need for research to determine the benefits obtained after the implementation of the system.
\end{abstract}

Keywords: Enterprise resource planning (ERP), earnings management.

\section{Introduction}

Accounting is a business language agreed upon by all parties as a tool in measuring the financial performance of a business organization and is used as a basis for making business decisions by all related parties (stakeholders) so that the financial statements presented must be impartial, reliable and timely. Earnings information, as part of financial statements, is often the target of engineering through opportunistic management actions to maximize satisfaction but can be detrimental to shareholders or investors. These opportunistic actions are carried out by choosing certain accounting policies so that the company's profits can be regulated, increased, or reduced according to their wishes. Management behavior to regulate earnings in accordance with their desires is known as earnings management. Healey and Wahlen (1999) state that earnings management occurs when managers use judgment in financial reporting and the preparation of transactions changes financial statements. This situation can mislead stakeholders about the company's economic performance and affect the results in relation to contracts that depend on the accounting numbers reported [1].

Scott (2012) earnings management is a management intervention in the process of preparing financial statements for external parties so that it can flatten, increase, and decrease earnings reporting, where management can use the leeway to use accounting methods, make policies (discretionary) that can accelerate or delay costs -costs and revenues, so that the company's profits are smaller or larger as expected. In the principle of financial reporting, 
financial statements must be reported as well as possible so as not to mislead stakeholders [2]. But in practice, accounting itself allows management to do earnings management. Quality accounting information is information that meets the qualitative characteristics of accounting information, namely, relevance, reliability, comparability, and consistency [3].

Earnings management is an active profit manipulation such as bookkeeping, choosing the use of allocation methods, accelerating or increasing recognition of a transaction in one period to another, all done by agents with various specific motives, such as obtaining and maintaining loan funds, avoiding taxes, bonus plans, and so forth. Earnings management can be described as management behavior in choosing certain accounting policies aimed at influencing earnings to achieve a certain goal. According to agency theory, earnings management always tries to maximize its utility function. Because management has the discretion to choose one accounting policy from generally accepted principles, then it is natural if the thought arises that management will choose an accounting method that specifically will help management in achieving its objectives. Financial statements containing earnings management cause the quality of accounting information produced is low. This information cannot describe the actual state of the company or its low relevance.

Enterprise Resource Planning (ERP) is a software system that integrates data and information from all of the company's functional areas, which include finance, accounting, production, sales, purchasing, human resources, and other functions [4]. The presence of an ERP system is certainly expected to have a positive impact on the accounting information generated because of its ability to cut reporting lines so that it can reduce reporting modifications in each of its sub-systems and will eventually produce reports that describe the actual conditions. According to Tarigan (2009), the implementation of an ERP system provides good information for companies because it can provide detailed and complete information, in addition to the high efficiency, especially in the operational section because it gets correct and timely information [5]. Task Technology Fit (TIF) developed by Goodhue and Thompson (1995) is the level at which technology helps individuals in carrying out their duties or job duties. High performance has implications for efficiency improvements, effectiveness improvements, and/or quality improvements [6].

The socio-technical theory proposed by Jenkins (2012) socio-technical system (STS) in organizational development is an approach to the design of complex organizational work that recognizes the interaction between humans and technology in the workplace. The use of ERP technology is equipped with hardware and software that functions to coordinate and integrate information data in each area of business processes so as to produce quick decision making because it provides quick analysis and financial reports, lampoon time sales reports, production, and inventory reports.

Tsai's research (2012) suggests that ERP system performance can reduce earnings management [7], while Wibisono research (2013) found that ERP system implementation is not able to significantly reduce the level of earnings management in financial statements [8]. Marjulin (2016), in his research findings, suggested that ERP systems can improve the quality of accounting information [9]. Research by Brazel and Li dang (2008) proves that ERP systems have a positive effect on earnings management. The implementation of an ERP system can improve earnings management by agents to fulfill their incentives due to increased access and control of information as well as a reduction in audit quality control and internal control [10]. Brazel and Agoglia (2007) suggest that assessing audit quality and internal control may be inadequate for clients who have implemented ERP systems, and there are concerns in practice with regard to the competence of IT auditors assigned to test ERP systems [11]. 


\section{Research Methodology}

This type of research secondary data collected by downloading data from the official website of the IDX (www.idx.co.id). The population of this research is manufacturing companies listed on the Indonesia Stock Exchange (IDX). The sample of this research is companies that meet the criteria of purposive sampling with the following criteria: (a) Companies that have implemented an ERP system, (b) basic and chemical industrial companies listed on the Stock Exchange starting 2013, (c) companies have annual reports in the study period and (d) companies that have complete data during the observation period. The sample in this study is in the form of an annual financial report.

\section{Result and Discussion}

There were 50 companies that did not implement the ERP system in the study period, four companies that did not have an annual report in the study period, two companies did not have complete data during the observation period, so that from 67 companies only 11 companies were sampled in this study.

It is known that for the average before ERP system implementation is -.0663297 and after ERP system implementation is -.0497521, meaning that the average before ERP system implementation is lower than the average after ERP system implementation.

Based on the histogram display, it can be seen that the dependent curves and standardized residual regressions form images such as bells, and the normalized appearance of standardized $\mathrm{p}-\mathrm{p}$ regression plots shows that the points spread around the diagonal lines. Therefore based on the normality test, regression analysis is feasible. Multicollinearity test results indicate that the ERP variable has a VIF value and tolerance values of 1.000 and 1.000 , respectively. This means it can be concluded that there is no multicollinearity between variables in the regression model. There was no autocorrelation because the Durbin-Watson (1.949) value was located between the value $d u=1.663$, and the 4 -du value $=2.333$ [12]. In the regression, model heteroscedasticity does not occur. This is because of Sig. ERP variable on absolute residuals is $0.515>0.05$ [12].

In this study, using the average difference test, Paired Samples T-Test is used to test the differences in two groups of paired data. For output describing the correlation between variables, it can be seen the value of the correlation between before and after ERP system implementation is 0.439 with a significance of 0.011

The result of the $t$ value is -859 . Distribution tables are sought at $a=5 \%: 2=2.5 \%(2-$ tailed test) with degrees of freedom $(\mathrm{df}) \mathrm{n}-1$ or $33-1=32$. With 2 -sided testing (significance $=$ $0.025)$, the results obtained for $t$ table amounted to 2.325 . because $-t$ count $>-t$ table $(-859>-$ 2.325) then $\mathrm{H} 0$ is accepted meaning there is no difference in the level of earnings management between before and after ERP system implementation with this it can be concluded that with the implementation of the ERP system is not able to reduce the level of earnings management in the company. These results are in line with previous research conducted by Wibisono (2013) that ERP implementation is not able to significantly reduce the level of earnings management in financial statements [8].

\section{Conclusion}


We conclude that the magnitude of investment value and exceed expectations of ERP system implementation are the reasons for the need to do research to find out the benefits obtained after the implementation of the system, especially on the financial statements produced, because financial statements are one of the main sources of information used by users to determine the decision. After conducting various analyzes of this study, the ERP system implementation was not able to reduce the level of earnings management, as indicated by statistical testing. These results indicate that the financial statements produced with the ERP system are not able to reduce the manipulation of financial data. This is not in accordance with accounting standards that say that financial statements must present the actual and honest condition of the company (representational faithfulness).

Research that measures the success of the system to produce information has not been done much; it is also necessary to research how the system produces accurate and accurate information for its users, especially financial information that is in accordance with accounting standards in force in Indonesia. This study tries to reveal the benefits generated from the implementation of the system seen from the results of the financial statements produced. But this research still has many shortcomings that must be completed by further research. This study uses only one dependent variable; namely, the value of earnings management in subsequent studies need to add other variables to describe the quality of financial statements produced by the system used by the company. Especially financial statements that must meet accounting standards in Indonesia.

\section{References}

[1] Healy. P and Wahlen. J.: A Review of The Earnings Manajement Literature and Its Implications for Standard Setting. Accounting Horizon (1999).

[2] Scott. W. R.: Financial accounting theory, 6th ed. Prentice Hall Upper Saddle River, NJ (2012).

[3] Donald. E. K, Weygandt. J. J., and Warfield. T. D.: Accounting Principles, 12th ed. Salemba Empat. Jakarta (2007).

[4] Suryalena.: Enterprise Resource Planning (ERP) Sebagai Tulang Punggung Bisnis Masa Kini. Jurnal Aplikasi Bisnis. pp. 145-154 (2013).

[5] Tarigan.: Pengaruh Key User Terhadap Kinerja Perusahaan Pada Implementasi Teknologi Enterprise Resources Planning. Framework Reearch. vol. 4, no. 3 (2009)

[6] York. G and Thompson.: Task-Technology Fit and Individual Performance. New York: McGraw-Hill (1995).

[7] Tsai, Hsien. W, Chou. K. C. L, Liu. W. J. Y, and Yu. S. J. L.: The Influence of ERP System's Performace on Earnings Management. Journal Enterprise Information Systems.. vol. 6, no. 4 (2012).

[8] Wibisono.: The Impact ERP System Implementation on Earning Management and Timeliness Financial Statement (Empirical Studies) On Adopters SAP in Indonesian Stock Exchange. Jurnal Analisis Bisnis Ekonomi. vol. 11, no. 2 (2013).

[9] Marjulin.: Success System Of Enterprise Resource Planning (Erp) Implications To The Quality Of Accounting Information. Uropean Journal of Accounting, Auditing and Finance Research. vol. 4, no. 7, pp. 43-50 (2016).

[10] Brazel. J. F and Li. D.: The Effect Of ERP System Implementations On The Management Of Earnings and Earnings Release Dates. Journal of Information Systems.vol. 22, no. 2, pp. 1-21 (2008).

[11] Brazel. J. F and Agoglia. C. P.: An examination of auditor planning judgments in a complex accounting information system environment. Contemporary Accounting Research 24 (Winter). pp. 1059-1083 (2007).

[12] Suliyanto.: Ekonometrika Terapan: Teori dan Aplikasi dengan SPSS. Andi: Yogyakarta (2011). 